\title{
Communication in the Migrant Community in Malta
}

\author{
Helen Grech ${ }^{a}$ Li-Rong Lilly Cheng ${ }^{b}$ \\ a University of Malta, Msida, Malta; ${ }^{b}$ San Diego State University, San Diego, Calif., USA
}

\section{Key Words}

Communication $\cdot$ Migrant community $\cdot$ Malta

\begin{abstract}
Aims: The study aimed to obtain information about communication in the migrant community in Malta. The objectives were to identify the communication skills of the migrants in terms of language use and exposure; to verify whether members of the migrant community have access to participation, education, socialization and opportunities for gainful employment, and to identify if the migrant community is willing to share insights. Method: A questionnaire was specifically devised to collect data via structured interviews. The project targeted candidates seeking refugee status. Forty immigrants consented to participate and were interviewed with the help of interpreters and carers. Results: Results indicate that migrants seem to experience different levels of adaptation and assimilation into the host cultural and social network. Some feel marginalized, while others seem to be adjusting to the new culture; these individuals also reported minimal to no difficulties with communicating with the local people. Communication among themselves was reported to be difficult for some, even though most of the migrants hailed from North Africa. Conclusion: The study provides an overview of challenges identified and highlights the need for service providers to identify cultural and linguistic characteristics to optimize their interpretation of behaviour.
\end{abstract}

(C) 2010 S. Karger AG, Basel

$1021-7762 / 10 / 0625-0246 \$ 26.00 / 0$

Fax +4161306 1234

E-Mail karger@karger.ch

www.karger.com
Accessible online at: www.karger.com/fpl

\section{Introduction}

The world population is increasingly becoming multilingual, particularly because of the proliferation of media, progress in information technology, the drive for lifelong learning and the increase in legal and illegal mobility. As many researchers argue, balanced bilingual or multilingual individuals do not exist; very often the proficiency in the languages differs. New immigrants are often challenged by unfamiliar and unclear cultural situations and, because of their limited proficiency in the language(s) of the country in which they land, they feel marginalized and find it difficult to interact with the 'native' population. Cheng [1] claims that though immigrants differ linguistically, culturally and socioeconomically, they seem to share common characteristics such as their insufficient knowledge and/or use of a different accent of the official language(s) of the country in which they land. She also reports that immigrants often have different medical/social experiences as well as different educational backgrounds and home-language literacy skills when compared with the 'natives'.

Theoretical underpinnings point out how culture and social relationships influence the acquisition of communication skills in children. For example, the information processing theory addressed by Bates and MacWhinney $[2,3]$ claims that language acquisition is motivated by the communicative goal of the child. The pragmatic theory described by Bruner [4] highlights the contextual situa- 
tion and communicative functions as the motivation for language acquisition. On the other hand, the social interaction theory suggests that the child-caregiver interaction drives language development in the context of biological and environmental influences [5]. Children of migrant families are therefore faced with a (sometimes conflicting) multitude of cultural values/beliefs and social rules that would influence their communication development (in particular their pragmatic skills).

Different cultural practices also impact on attitudes, such as the need for referral to professional services, including speech and language therapy, the drive for education and literacy skill development as well as the need to interact with individuals coming from other cultural backgrounds. Hwa-Froelich and Vigil [6] insist that responsibility, interpersonal relationship rules and risk management are culture specific. The authors provide scenarios to illustrate the influence of these factors on the communication of migrants as well as on the pattern of language acquisition that their children will follow. Professionals such as speech-language pathologists must understand these cultures as they may otherwise misinterpret behaviours, which could lead to misdiagnoses. For example, culturally acceptable lack of turn-taking or avoidance of eye contact could reflect negatively in an assessment of pragmatic skills unless the professional is aware of the cultural 'norms'. Such behaviour may also be misinterpreted as a socially unacceptable/disrespectful behaviour by service providers with the consequence of having a breakdown in communication. Battle [7] explains how communication and culture are intertwined and discusses how cultural differences, beliefs and attitudes affect the assessment, diagnosis and intervention by speech-language pathologists.

It is therefore crucial that, before embarking in service provision, cultural and linguistic characteristics are identified to optimize the interpretation of behaviour, to gain trust and respect and to build an effective professional relationship with the diverse service users. This should then lead to the provision of effective customized services.

Cheng and Butler [8] report that immigrants may experience diverse levels of adaptation and incorporation into the host cultural and social network. Initially, immigrants may reject the new culture and language and try to retain theirs in the host country. At a second level, the immigrants may then attempt to blend a selection of the two cultures. Another identified level is when immigrants reject or withdraw from their native culture or the new culture; however, this often leads to isolation. An attempt to accept both cultures but not to integrate into either one seems to be more constructive though this may give immigrants a feeling of marginalization and uncertainty as to which rules to abide by. The full involvement of both cultures, termed biculturalism, reflects the confidence in being integrated in both cultures and often means that the individuals become proficient in the language(s) of the host country as well. At the highest level of adaptation there is integration and mainstreaming into the new culture to the extent that the native culture and language are rejected. Battle [7] explains that asylum seekers (seeking refugee status) may have low levels of assimilation into the host country as they are normally forced to leave their countries, go through a negative experience during the migration process and have little if any knowledge of and preparation for the new culture. Consequently, they end up with culture shock and feel marginalized for long periods.

This scenario has recently been captured in Malta when the European Commissioner for Justice, Freedom and Security visited the 'illegal migrants' in detention in Malta [9]. During his short stay, the Commissioner was struck by the anguish of young migrants who expressed their wish to build a better future. The migrants informed the Commissioner that the process of their request for asylum status caused them mental stress and that Malta's reception conditions were unsatisfactory. The number of illegal migrants in Malta is escalating and the Maltese consider this 'silent invasion' as being threatening, while perceptions of xenophobia and racism are becoming apparent. Such bipolar attitudes are bound to reflect on communication within and outside the migrant community. It was therefore considered crucial to explore this scenario and to obtain accurate and current information about the communication of the migrant community in Malta with the mainstream migrant and local communities with the purpose of providing better services.

The Maltese Islands are strategically located between the migratory route from North Africa to Italy; consequently, the inflow of illegal immigrants has shot up on the Islands in the last 10 years. Illegal immigration is considered a serious issue in Malta since it is a densely populated country with approximately 450,000 inhabitants. During the ongoing parliamentary debate on the issue of illegal immigration, the opposition leader in Malta reported that 12,000 immigrants have entered Malta in the last decade. Prior to the year 2002, only 30-40 illegal immigrants were reported to have landed on Malta. The quoted figure of the current 'illegal immigrants' in Malta is 52,000 [10]. Malta has no agreed quota above which it does not accept, protect or help illegal immigrants. The 
former Minister of Home Affairs was reported to state that this does not imply that Malta has an open invitation for illegal immigrants; however, it intervenes when distress at sea is identified. Malta has been criticized for taking such a stand. The Members of Parliament acknowledge that the issue of illegal immigration is not a political one and measures are being taken to control such immigration and repatriate immigrants. This issue is also being discussed at EU level; in fact, Malta put illegal immigration on the EU agenda and under the French presidency, the immigration pact was compiled.

The Prime Minister of Malta acknowledges that the solution to be sought should reflect the Island's Christian values and characteristics related to respect for such beings. This is already being implemented since the Armed Forces of Malta and the Malta Police Force have helped boatloads of such individuals in distress. These governmental bodies normally intervene to save the illegal immigrants on their arrival in Maltese territorial waters. In some situations these Maltese officers risk their own lives for the sake of these migrants. Malta's guidelines indicate that the nearest vessel should be responsible for helping distressed boatloads of immigrants who should then be landed on the nearest country to where they were picked up. However, since Malta is central to the migration flow, the government of Malta considers the current state of affairs as being worrisome.

Malta is the only EU member state which has an automatic policy determining who is kept under detention on entry. Immigrants in Malta are not released easily and not before 6 months in detention in spite of international pressure. However, children and their parents are kept outside detention centres. There are still many unresolved challenges. It seems that the state of these detention centres needs to be improved. It is not uncommon to have occasional riots in detention centres seemingly related to unclear issues because of difficulties in communication between the local bodies and the migrant communities.

Accurate and current information about the communication of the migrant community in Malta with the mainstream migrant and local communities is needed so as to inform policy makers and service providers about the state of the art and to offer more customized services to the migrant community. It was therefore decided to carry out a survey among the Maltese asylum seekers with this goal.

The objectives of the study were to identify whether:

- communication is facilitated in a culturally and linguistically appropriate manner;
- the minors in the migrant community receive adequate stimulation for the development of languages within a multilingual context;

- members of the migrant community have access to participation and socialization in the mainstream;

- members of the migrant community have gainful employment;

- a language barrier exists that could prevent opportunities for employment;

- this migrant community is willing and ready to share insights to improve the quality of services provided to them.

Data about the migrants' own communication skills in terms of language use and exposure were also required for the purpose of the study.

\section{Methodology}

A questionnaire was specifically devised to address the objectives of this study (see Appendix). The questionnaire was written in English but was transmitted in the mother tongues via interpreters when considered necessary. Initially, the project was targeted towards all candidates seeking refugee status in Malta. Following an interview with the operations director of the Organisation for the Integration and Welfare of Asylum Seekers in Malta and the person in charge of the minors, permission was granted to collect data from 3 of the centres around Malta. Permission from the Children and Young Persons Advisory Board was also granted as well as by the University Research Ethics Committee. During the interview it was indicated that the migrants in these centres hail from different parts of the world, mainly North Africa. It was also indicated that most of the residents had very basic education and that difficulty could be encountered to obtain their cooperation (even through their interpreters) to collect the data. Since it was also pointed out that the officer in charge of each centre may not have time to chase the questionnaires and that the respective homes were short staffed, interviews with the officers in charge of these centres and the interpreters were conducted to seek their opinion as to the best method of collecting the data. These officers suggested that the researchers address the purpose and objectives of the survey during one of their monthly meetings with the residents. This was followed by structured interviews with individual migrants or the families with the help of the interpreters.

\section{Sample Population}

A total of 89 immigrants resided in the 3 homes at the time of data collection. These included 14 adult males, 25 adult females, 25 unaccompanied minors under a care order and 25 other minors (accompanied by their caretakers) (table 1). Their respective country of origin varied though most of them hailed from Somalia, Ethiopia, Nigeria or Eritrea. The age range was not restricted; in the case of minors, information was obtained via their caretakers. No exclusion criteria were proposed. 


\section{Results}

Forty immigrants consented to participate and were interviewed with the help of interpreters and respective carers; 13 of them were minors, while 26 were adults. Figure 1 indicates the language use of the migrants. In all, $15.4 \%$ of the minors and $26.9 \%$ of the adults reported that they were proficient in English. With regard to the Maltese language, $15.4 \%$ of the minors and $11.5 \%$ of the adults claimed to have some knowledge of spoken Maltese. A relatively high percentage of the interviewed immigrants spoke Arabic. The immigrants were less proficient in written language (fig. 2). Only 1 female minor had some knowledge of written English, while 5 male minors were reported to have some proficiency in written English. As for the adults, there were more females with some knowledge of written English when compared to the adult males. None of the adults were proficient in written Maltese and only 1 male minor reported some knowledge.

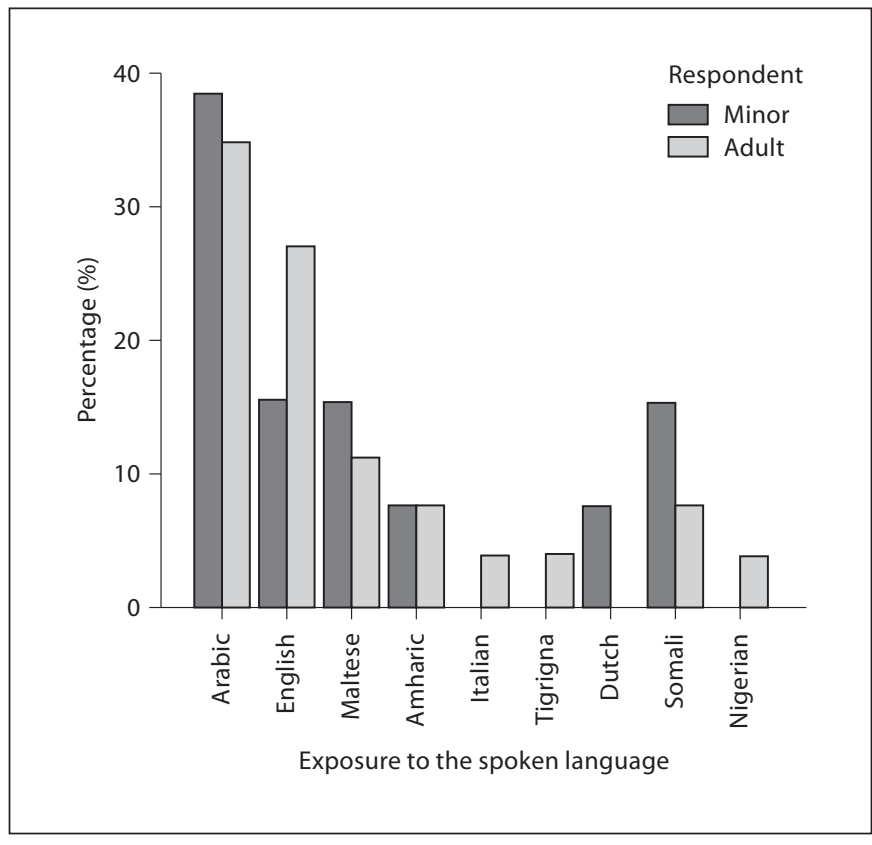

Fig. 1. Exposure to the spoken language.

Table 1. Details of population in the 3 selected homes

\begin{tabular}{|c|c|c|c|c|c|c|}
\hline & $\begin{array}{l}\text { Number } \\
\text { of residents }\end{array}$ & Origin & Gainful employment & Age range/gender & \multicolumn{2}{|l|}{ Financial support ${ }^{1}$} \\
\hline Home 1 & 38 & $\begin{array}{l}20 \text { Somalia } \\
7 \text { Ethiopia } \\
8 \text { Nigeria } \\
2 \text { Cameroon } \\
1 \text { Malaia } \\
\text { (Romania) }\end{array}$ & $\begin{array}{l}3 \text { male adults } \\
4 \text { male adults } \\
\text { work on casual basis }\end{array}$ & $\begin{array}{l}5 \text { male adults } \\
12 \text { female adults } \\
10 \text { unaccompanied } \\
\text { minors under care order }{ }^{2} \\
6 \text { accompanied male } \\
\text { minors } \\
5 \text { accompanied female } \\
\text { minors }\end{array}$ & $\begin{array}{l}\text { adults in open centres/ } \\
\text { homes have daily } \\
\text { allowance }{ }^{3} \text {, subject to } \\
\text { status of migrant } \\
\text { - asylum seekers and } \\
\text { subsidiary protection } \\
\text { - refugee status } \\
\text { - returnees } \\
\text { - rejected status } \\
\text { parents receive child } \\
\text { allowance }\end{array}$ & $\begin{array}{l}\text { 4.66 Euro } \\
\text { 4.08 Euro } \\
\text { 2.91 Euro } \\
\text { 3.49 Euro } \\
\text { 2.33 Euro }\end{array}$ \\
\hline Home 2 & 37 & $\begin{array}{l}18 \text { Somalia } \\
9 \text { Eritrea } \\
6 \text { Ethiopia } \\
3 \text { Nigeria } \\
1 \text { Sudan }\end{array}$ & 7 male adults & $\begin{array}{l}9 \text { male adults } \\
13 \text { female adults } \\
1 \text { under care order } \\
14 \text { minors }\end{array}$ & \multicolumn{2}{|l|}{ same as above } \\
\hline Home 3 & 14 & $\begin{array}{l}9 \text { Somalia } \\
2 \text { Nigeria } \\
2 \text { Ethiopia } \\
1 \text { Mali }\end{array}$ & 2 & $\begin{array}{l}14 \text { unaccompanied minors } \\
\text { under care order }\end{array}$ & \multicolumn{2}{|c|}{$\begin{array}{l}\text { on arrival, residents receive } 5 \text { Euro } \\
\text { for telephone card; } 70 \text { Euro for } \\
\text { necessities; those not in gainful } \\
\text { employment receive } 7 \text { Euro weekly }\end{array}$} \\
\hline $\begin{array}{l}1 \text { Tho } \\
\text { aid. If th } \\
\text { weekly c } \\
{ }^{2} \text { Una } \\
\text { of age. T }\end{array}$ & $\begin{array}{l}\text { who are gain } \\
\text { do not regist } \\
\text { tribution of } 8 \\
\text { ompanied mi } \\
y \text { have the sar }\end{array}$ & $\begin{array}{l}\text { fully employed } \\
\text { ter } 3 \text { times wee } \\
.20 \text { Euro. } \\
\text { nors under care } \\
\text { me rights and o }\end{array}$ & $\begin{array}{l}\text { do not receive financial } \\
\text { y, they are due to pay a } \\
\text { order are under } 18 \text { years } \\
\text { ligations as Maltese na- }\end{array}$ & $\begin{array}{l}\text { tionals under care order. } \mathrm{O} \\
\text { to an open centre. } \\
{ }^{3} \text { All immigrants have } \\
\text { vices and medication. Mot } \\
\text { the first } 6 \text { months after giv }\end{array}$ & $\begin{array}{l}\text { reaching } 18 \text { years, they a } \\
\text { ee education, health, soc } \\
\text { ers get free milk and nap } \\
\text { g birth. }\end{array}$ & $\begin{array}{l}\text { al care ser- } \\
\text { pies during }\end{array}$ \\
\hline
\end{tabular}


Fig. 2. Knowledge of written language. a Minors. b Adults.

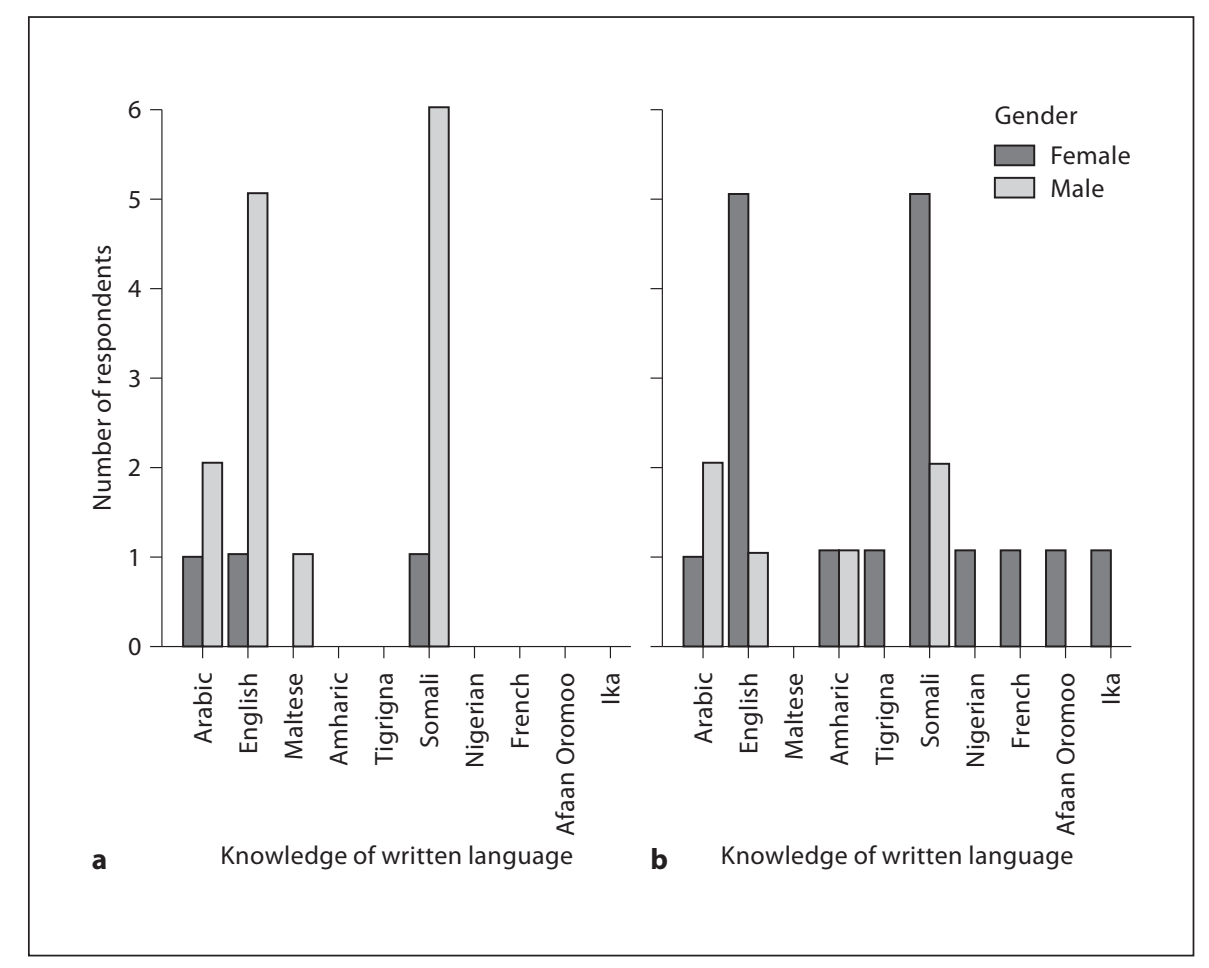

Thirty informants agreed to comment about their level of education. The respective information is summarized in table 2. Only 2 (6.67\%) of the respondents reported having tertiary education, while 8 (26.67\%) claimed that they had never received any formal education.

When asked if they had pre-existing medical conditions, 30 subjects chose to reply. The majority of the respondents (76.67\%) indicated that they did not have any medical condition and only 5 chose to name the condition (tables 3,4$)$. The conditions that the migrants reported were very different to what was on record. Fourteen migrants chose to mention their employment/profession in their home country (table 5). Of all respondents, 28 reported whether or not their income was related to gainful employment; $70 \%$ gave a negative reply, while $30 \%$ claimed that they had gainful employment.

Table 6 summarizes the responses related to the immigrants' satisfaction with communication within their community. More than half of the respondents complained of experiencing difficulties with communicating in Malta. Half of the adults who opted to comment on the communication within the immigrant community explained that they were satisfied, while the other half expressed their concern. The under-18-year-olds were more satisfied with the communication amongst themselves and out of the 15 who replied only 1 expressed dissatisfaction. Reasons that they gave for their dissatisfaction included lack of understanding each other's language, overcrowding and regular arguments.

When asked if they were satisfied with their communication with the Maltese community, $64 \%$ of the 36 who replied answered in the affirmative, while $36 \%$ were dissatisfied and gave several reasons for their dissatisfaction as indicated in figure 3. Some also expressed dissatisfaction with the education that their children were receiving in Malta. More than half the respondents were also dissatisfied with the service of interpreters. The questionnaire also tried to capture the immigrant's awareness of the speech therapy service. Most of the respondents (83\%) were unaware that this service exists. Suggestions posed by the migrants to improve the service they receive in the host country include opportunities for learning to read and write in English and/or Maltese, transport to the hospital and better work opportunities. There were a number of migrants who mentioned that they would not like to stay in Malta. 
Table 2. Highest level of education by gender and chronological age (n)

\begin{tabular}{llll}
\hline \multicolumn{2}{l}{ Highest level of education } & Total \\
\cline { 2 - 3 } $\begin{array}{l}\text { no edu- pri- } \\
\text { cation }\end{array}$ mary & $\begin{array}{l}\text { sec- } \\
\text { ondary }\end{array}$ & ondary sec- ter- & \\
\hline
\end{tabular}

\section{Female}

$15-18$ years

$19-25$ years

26-35 years

36-45 years

Total

Male

$\begin{array}{llllll}0-5 \text { years } & 0 & 1 & 0 & 0 & 1 \\ 10-14 \text { years } & 1 & 3 & 0 & 0 & 4 \\ 15-18 \text { years } & 1 & 0 & 3 & 0 & 4 \\ 19-25 \text { years } & 0 & 2 & 1 & 0 & 3 \\ 26-35 \text { years } & 0 & 1 & 0 & 1 & 2 \\ \text { Total } & 2 & 7 & 4 & 1 & 14\end{array}$

Table 3. Reported preexisting medical condition by gender and chronological age (n)

\begin{tabular}{|c|c|c|c|}
\hline & \multicolumn{2}{|c|}{$\begin{array}{l}\text { Do you have any pre- } \\
\text { existing medical condition? }\end{array}$} & \multirow[t]{2}{*}{ Total } \\
\hline & yes & no & \\
\hline \multicolumn{4}{|l|}{ Female } \\
\hline 15-18 years & 0 & 2 & 2 \\
\hline $19-25$ years & 2 & 6 & 8 \\
\hline $26-35$ years & 1 & 3 & 4 \\
\hline $36-45$ years & 1 & 0 & 1 \\
\hline Total & 4 & 11 & 15 \\
\hline \multicolumn{4}{|l|}{ Male } \\
\hline $0-5$ years & 1 & 0 & 1 \\
\hline 6-9 years & 1 & 0 & 1 \\
\hline $10-14$ years & 0 & 4 & 4 \\
\hline $15-18$ years & 0 & 5 & 5 \\
\hline $19-25$ years & 1 & 2 & 3 \\
\hline $26-35$ years & 0 & 1 & 1 \\
\hline Total & 3 & 12 & 15 \\
\hline
\end{tabular}

Table 4. Specific preexisting condition by gender and chronological age (n)
Table 5. Former profession or occupation by gender and chronological age (n)

\begin{tabular}{|c|c|c|c|c|c|c|}
\hline & \multicolumn{5}{|c|}{ If so, please list preexisting condition } & \multirow[t]{2}{*}{ Total } \\
\hline & $\begin{array}{l}\text { bullet } \\
\text { in legs }\end{array}$ & unclear & $\begin{array}{l}\text { heart } \\
\text { problems }\end{array}$ & asthma & $\begin{array}{l}\text { heart and } \\
\text { neck problems }\end{array}$ & \\
\hline \multicolumn{7}{|l|}{ Female } \\
\hline $19-25$ years & 1 & 0 & 0 & & 1 & 2 \\
\hline $26-35$ years & 0 & 0 & 1 & & 0 & 1 \\
\hline $36-45$ years & 0 & 1 & 0 & & 0 & 1 \\
\hline Total & 1 & 1 & 1 & & 1 & 4 \\
\hline \multicolumn{7}{|l|}{ Male } \\
\hline $0-5$ years & & & & 1 & & 1 \\
\hline Total & & & & 1 & & 1 \\
\hline
\end{tabular}

Total

\begin{tabular}{llllll}
\hline no & yes & shop & fashion & plas- & construc- \\
keeper & designer & terer & tion worker & dresser
\end{tabular}

\section{Female}

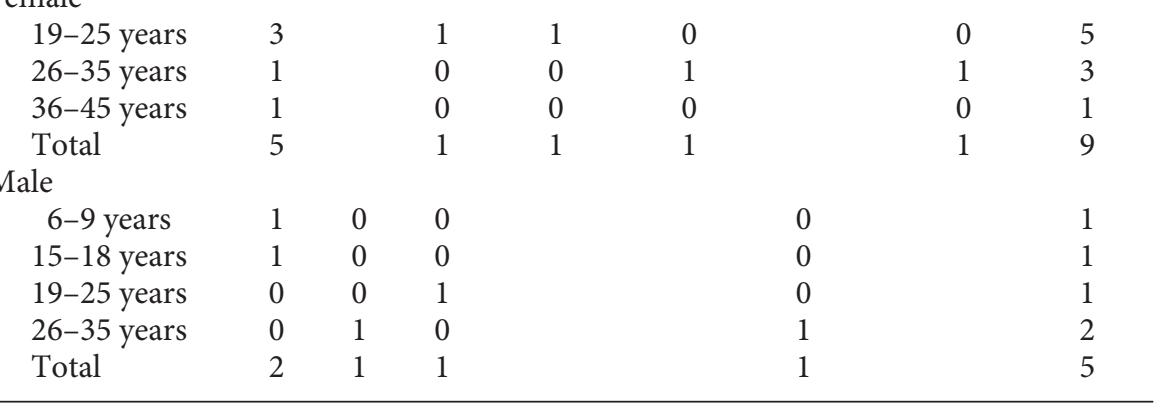


Table 6. Satisfaction with communication within the immigrant community by gender and age group (n)

\begin{tabular}{lrrr}
\hline & \multicolumn{2}{c}{$\begin{array}{l}\text { Are you satisfied with communication } \\
\text { within the immigrant community? }\end{array}$} & Total \\
\cline { 2 - 3 } & yes & no & \\
\hline Female & & & 3 \\
Minor & 2 & 1 & 15 \\
Adult & 8 & 7 & 18 \\
Total & 10 & 8 & 12 \\
Male & & & 5 \\
Minor & 12 & 0 & 17 \\
Adult & 2 & 3 & \\
Total & 14 & 3 & \\
\hline
\end{tabular}

\section{Discussion}

The survey attempted to capture feelings and attitudes of some of the asylum seekers in Malta. The overall trends indicate that a number of migrants are still suffering from culture shock and feel marginalized. As indicated by Cheng and Butler [8], immigrants seem to experience different levels of adaptation and assimilation into the host cultural and social network. A few migrants seem to be adjusting better to the new culture and indicated some proficiency in the Maltese and/or English language; these individuals also reported minimal to no difficulties with communicating with the local people. However, a high proportion of the immigrants seem to be rejecting the new culture and language, and by trying to retain theirs in the host country, they end up feeling dissatisfied with the service they receive. Communication among themselves is not easy either. Although most of them hail from North Africa, their culture and language still vary significantly. When they end up living in the same closed centre, this tends to create conflicts and further challenges that pushes them further from adaptation.

Meanwhile, strategies have been taken by the local government to better the services to migrants. Since 2003, 895 migrants have registered as gainfully employed and paying national insurance contribution and taxes, while 2 are employers. The Maltese government also plans to improve the state of detention centres and security, the training of migrants, application of an admissions policy to detention centres, and helping communities in open and closed centres. However, it seems that the underlying core issue of migrant dissatisfaction is the

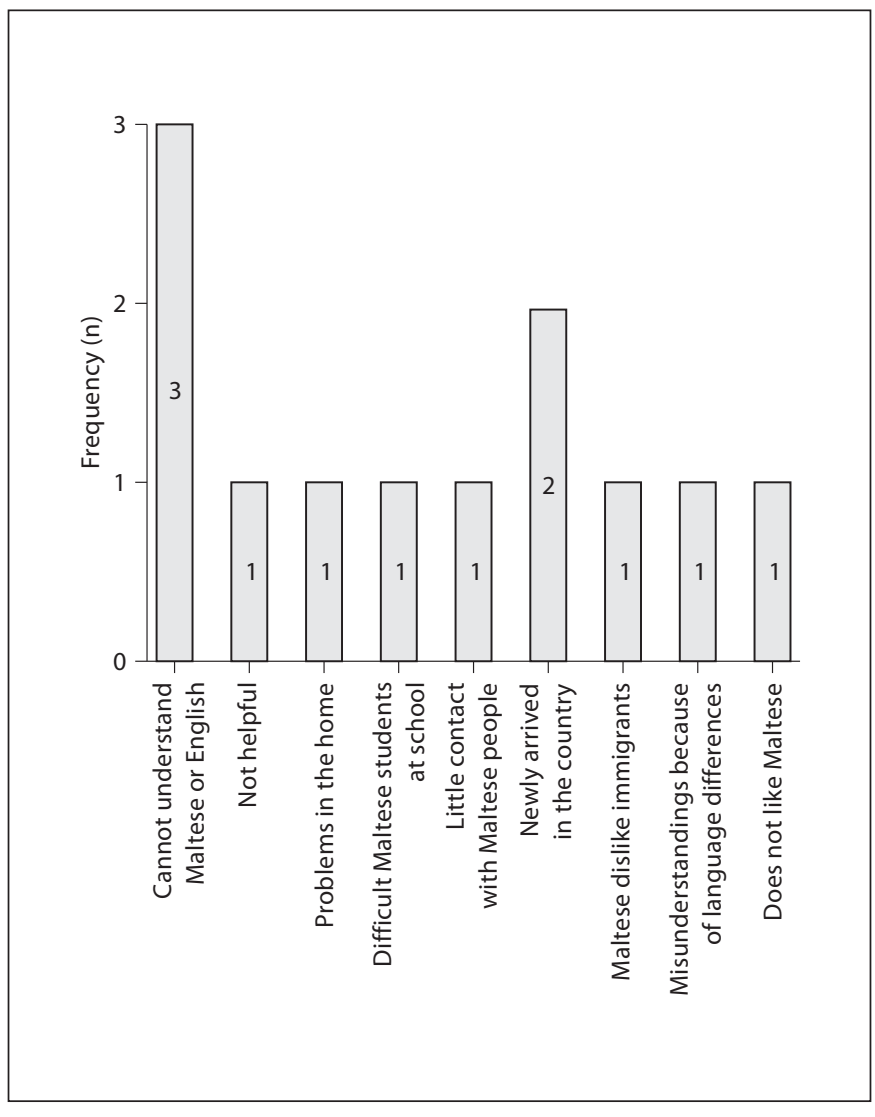

Fig. 3. Communication with the Maltese population.

difficulty they encounter in communicating. Communication is a basic human need, and behavioural and multiple aggregating difficulties may be the consequence of difficulties in communication. In the case of children, the literature clearly marks an overlap between communication difficulties and other areas of functioning such as school-peer relations, behaviour/conduct and attention/learning/cognitive skills. This survey should serve as an eye-opener for the host country and other states receiving illegal migrants. It provides an overview of problem areas identified and highlights the need that, before embarking in service provision, cultural and linguistic characteristics should be identified to optimize the interpretation of behaviour and gain the trust of the diverse service users. 


\section{Appendix}

\section{General Information}

1. Current age (years and months)

2. Date of Birth

3. Male $\square \quad$ Female $\square \quad$ Tick $\sqrt{ }$ where applicable

4. Language use: Primary language __ Home language if different

5. Language Language exposure: Have you been exposed to other languages besides Maltese If yes, which are the languages? and English throughout your life?

Can you read and write? If yes, which languages?

6. Highest level of education: (Tick $\sqrt{\text { where applicable) }}$

Primary $\square \quad$ Secondary $\square \quad$ Post secondary $\square \quad$ Tertiary $\square$

7. Socio-economic status (subsidy received): Do you receive any financial aids?

If yes, is it through employment?

8. Health services:

Health status (pre-existing conditions): Do you have any pre-existing medical conditions? If so, please list

9. Work setting:

Where do you work?

Are you being paid for any work that you perform?

Former profession or occupation (if applicable)?

10. Home environment: Period of stay in Malta (Please specify)

Detention centre (months/weeks):

Home (months/weeks):

11. Family composition (locations):

If outside Malta, please state

12. Religious practice (example: Muslim, Catholic):

\section{Communication}

13. Are you satisfied with your communication within the immigrant community?

14. Are you satisfied with the quality and frequency of communication with the Maltese mainstream community?

15. Are you satisfied with the quality of the interpretation services?

If not, please explain why

16. Are you experiencing difficulties in communication in Malta?

not, please explain why

17. Are you satisfied with the education services that your children are receiving in Malta? If no, please explain why

If yes, please provide specific encounters

18. Are you aware of the speech and language services offered in Malta?

19. Is any member of your family receiving speech and language services?

If not, do you think any member of your family living in Malta could benefit from such services?

20. Please provide suggestions for improvements of services received in Malta in general.

21. Is there any other relevant information that you would like to share?

\section{Thank You}




\section{References}

1 Cheng L: The challenge of hyphenated identity. Top Lang Disord 2004;24:216-224.

2 Bates E, MacWhinney B: Functionalist approaches to grammar; in Wanner E, Gleitmann LR (eds): Language Acquisition. The State of the Art. New York, Cambridge University Press, 1982, pp 173-218.

3 Bates E, MacWhinney B: Competition, variation, and language learning; in MacWhinney B (ed): Mechanisms of Language Acquisition. Hillsdale, Erlbaum, 1987, pp 157-193.
4 Bruner JS: Actual Minds, Possible Worlds. Cambridge, Harvard University Press, 1986.

5 Snow C: Social interaction and language acquisition; in Dale P, Ingram D (eds): Child Language. An International Perspective. Baltimore, University Park Press, 1981.

6 Hwa-Froelich DA, Vigil DC: Three aspects of cultural influence on communication: a literature review. Commun Disord Q 2004;3: 107-118.

7 Battle DE: Communication Disorders in Multicultural Populations, ed 3. Boston, Butterworth Heinemann, 2002.
8 Cheng L, Butler K: Difficult discourse: designing connections to deflect language impairment. Paper presented at the annual meeting of the California Speech-Language Hearing Association, Palm Springs, 1993.

9 Vella F: Europe has to provide young migrants with the opportunity to build a future - Barrot. The Malta Independent, March 15, 2009.

10 Sansone K: Sending migrants back is a must - PM. Times of Malta, March 18, 2009. 